https://doi.org/10.18485/kud_kiaz.2019.ch4

Мамед Алиев, доктор философских наук профессор Азербайджанского университета языков

\title{
АЗЕРБАЙДЖАНСКАЯ МОДЕЛЬ МУЛЬТИКУЛЬТУРАЛИЗМА
}

«Для каждого человека национальная принадлежность является источником гордости. Я всегда гордился и сегодня горжусь тем, что я азербайджанец!»

Общенаииональный лидер Азербайджана Гейдар Алиев

\section{SUMMARY}

This article is dedicated to the multiculturalism - actual problem of the contemporary period of the Republic of Azerbaijan. Today, the Azerbaijani model of multiculturalism is very authentic; this model is being studied not only in the country, but also in foreign countries. At the present time multiculturalism in the country is a state policy.

Key words: Azerbaijan, policy, multiculturalism, tolerance, culture, religion.

Мультикультурализм, толерантность и религиозная терпимость - неотъемлемые компоненты современного Азербайджана. Это связано с тем, что, развитие в Азербайджане мультикультурализма, толерантности и религиозной терпимости на уровне государственной политики основано на древней истории государственности страны и на развитии этих традиций. 
Еще со времен государства Сефевидов, а также в эпоху просветительства XIX-XX столетий и в период Демократической Республики на территории Азербайджана, наряду с азербайджанцами, проживали представители разных наций и народностей, этнических и религиозных групп.

В конце XX века, благодаря усилиям общенационального лидера Азербайджана Гейдара Алиева, это политическое поведение приобрело форму идеологии государственности, были восстановлены традиции толерантности и мультикультурализма. Политические основы азербайджанской модели мультикультурализма нашли свое отражение в соответствующих положениях статей Конституции Азербайджанской Республики, законодательных актах, указах и распоряжениях.

«Азербайджан на протяжении веков был пространством, где сливались различные религии, культуры и цивилизации. Мы - не только географический, но и культурный мост между Востоком и Западом. На протяжении истории представители различных религий и культур жили в Азербайджане в условиях мира, братства. Мультикультурализм является образом жизни в Азербайджане. Азербайджан - многонациональная и многоконфессиональная страна», - сказал президент Азербайджана Ильхам Алиев (3).

Интерес Азербайджанской Республики и общества к мультикультурализму, как к одной из важнейших стабилизационных парадигм, является ярким отражением ответственного подхода нашего государства к своей роли в системе национальных и глобальных координат. Процесс взаимодействия культур с отдельными системами цивилизаций особенно в первое десятилетие нового века стал явлением злободневным. Данный процесс определяет содержание современного и вместе с тем внутренне противоречивого, переходного периода посткоммунистических, а по другой терминологии - постсоциалистических стран. Каждое независимое государство стремится заимствовать 
ценности той системы, которая исторически уже сумела доказать некоторые свои политические преимущества.

Религиозная толерантность - она и ведущих черт азербайджанского народа. Она ка бы изначально заложена в генетическом коде людей. Причём, сочетание религиозного и политического компонентов в республике в известном смысле уникально, так как корни его уходят вглубь веков. Более того, религиозная толерантность лежала в основе целого ряда политических кризисов, сотрясавших государство, следовательно, всегда была тесным образом связана с политикой. Такое положение было предопределено еще в период зарождения политической системы и продолжало формироваться на протяжении всей истории нашей страны.

Характерно, что такие черты характера азербайджанского народа, как терпимость к другим нациям и конфессиям в Азербайджане охватывает не только собственно политику, но и другие сферы человеческой деятельности (культуру, идеологию, семейные отношения и т.д.), формируясь на основе человеческого поведения. Она (религиозная толерантность) в мультикультурном обществе в свою очередь базируется на трёх основных элементах умениях, навыках и соответствующем мировоззрении, отражающих базовые человеческие потребности - личные и общественные. Сочетание этих трех элементов вырабатывает те общественные устои, в рамках которых и существует то или иное общество. Учитывая, что преобразующее начало ярче всего реализуется в религии, становится очевидным, что структура большинства современных сообществ основана, в том числе и на вероучении.

В современном Азербайджане мультикультурализм - это целенаправленная государственная стратегия, которая в первую очередь направлена на достижение определённого уровня не антагонистического сосуществования разных культур. Поэтому в нашей республикемультикультурализм фактически предусматривает развитие и укре- 
пление богатого культурно-этнического разнообразия, включая сохранение и распространение среди населения религиозных ценностей.

Одной из самых действенных форм религиозной агитации в Азербайджане является проведение в жизнь идеи о том, что люди, относящиеся к разным этносам, должны непременно научиться жить бок о бок друг с другом. Тем самым они лучше и теснее взаимодействуют, но не отказываются от собственного культурного своеобразия. Самобытность отдельной культуры в нашей республике вместе с тем обеспечивается мирным сосуществованием групп людей со своей индивидуальной историей и культурой.

Мультикультурализм - это масштабное явление и ориентирует теоретиков на использование в своих трудах очень широкого и самого многообразного культурного контекста. Мультикультурализм в Азербайджане имеет прочные исторические корни. И опираются теории нашего мультикультурного государства тоже на древние и мудрые традиции. Разумеется, некоторые из них по истечении веков изменились по своей политической сути, но сохранились в том же религиозном культурном содержании. Многонациональная республика уже на рубеже XX-XXI столетий сумела найти наиболее оптимальное решение данного вопроса. Сущность его состояла, прежде всего, в восстановлении религиозно-культурного наследия: мечетей, монастырей, храмов, церквей и т.д. Так, например, комплекс мечети Гейдара был построен по указанию Президента Азербайджана Ильхама Алиева. В эксплуатацию он был сдан в 2014 году. На сегодняшний день эта мечеть - самая большая на Кавказе. Высота её минаретов составляет свыше 95 метров. Здесь огромные молитвенные залы, вмещающие в себя одновременно до 7000 человек.

В то же время в Баку за последние годы построена крупнейшая на Кавказе синагога, в Шекинском районе отреставрированы и охраняются законом христианские и католические церкви, православные храмы. В 2001 году в 
Баку реконструирован крупный православный храм - Coбор Рождества Пресвятой Богородицы. Весной 2008 года в Баку состоялась официальная церемония открытия католической церкви Пресвятой девы Марии. В церемонии открытия принимал участие Президент Азербайджана Ильхам Алиев.

С 1920 года в упадок пришёл собор святых Жён Мироносиц. Знаменит он тем, что в нём находится ковчег со святыми мощами Апостола Варфоломея. Ещё со времён русской революции он считался в Баку покровителем города. В те же годы были привезены иконы Божией Матери «Тихвинская» и «Каспийская». Эти иконы - реликвия храма. Они были забыты, как и заброшен сам храм. С 1991 года полуразрушенное здание было полностью восстановлено, передано во владение Русской православной церкви. После ремонтно-восстановительных работ 24 марта 2003 года состоялось открытие храма. В торжественном мероприятии принимали участие Президент Азербайджана Гейдар Алиев и председатель Управления мусульман Кавказа шейх уль-ислам гаджиАллахшукюрПашазаде. Храм ныне ежедневно функционирует, принимая прихожан разных национальностей.

15 ноября 2013 состоялось открытие Православного религиозно-культурного центра Бакинской и Азербайджанской епархии, построенного на территории Кафедрального собора Святых Жен-мироносиц. В церемонии его открытия также принимал участие Ильхам Алиев. Он подчеркнул: «Мы восстанавливаем все религиозные памятники, и Азербайджан является страной, где пересекаются религии, народы, которые всегда жили в мире, согласии, сотрудничестве. Мы по праву гордимся тем, что самая древняя церковь на Кавказе находится в Азербайджане, в небольшом селе около города Шеки. Одна из самых древних мечетей, которая была построена в 743 году, также находится в Азербайджане, в Шамахе, она восстановлена в этом году. В Баку также как памят- 
ник нашего исторического прошлого существует Храм огнепоклонников-зороастрийцев. Католическая церковь, которая была разрушена, также восстановлена, синагоги также строятся. То есть, это показатель развития нашего общества, в первую очередь, состояния общества, а также показатель государственной политики. И отрадно, что и состояние общества, и государственная политика в этих вопросах идут, как говорится, рядом» $(1,12)$.

Убеждены: всё отмеченное о строительстве или восстановлении ранее повреждённых мечетей, храмов, церквей, с одной стороны, свидетельствует о расширении в республике национального конфессионального пространства, которое сегодня, то есть спустя почти семнадцать лет в новом веке, позитивно сказывается на результатах гармоничного сосуществования людей различных вероучений. С другой стороны, опираясь на вышеприведённые слова Ильхама Алиева о тесном сращении государственной политики с нынешним состоянием общества, можно сделать однозначный вывод о том, что в основе генеральной стратегии правительства Азербайджана лежит религиозная толерантность как важнейшая составляющая мультикультурализма. Скажем больше того: тем самым Азербайджан являет собой показательный пример для многих государств бывшего Советского Союза по части гармоничного соединения теории мультикультурализма в трудах учёных с практикой его внедрения в повседневную жизнь.

Потому и не удивительно, что нередко в числе посетителей христианских церквей или православных храмов можно видеть представителей исконно азербайджанского населения. И это не случайно. Не во всех странах можно сегодня наблюдать такое единодушие по отношению к иному вероисповеданию.

Первый вице-президент Азербайджана Мехрибан Алиева отметила: «Моё главное желание - всецело сконцентрироваться на решении сложных и неординарных социальных проблем, прежде всего связанных с малообе- 
спеченными слоями населения. Истинное милосердие и толерантность требуют исполнения реальных дел и конкретных шагов. Самое страшное в обществе - это чёрствость и равнодушие. Этого не должно быть, и не суть важно - общественный ли ты деятель или работаешь на государственной службе. В любом случае, по моему глубокому убеждению, следует соблюдать человечность» $(6,3)$.

Таким образом, можно уверенно сказать, что в начале XXI века в Азербайджане в достаточной мере обеспечена свобода религиозного вероисповедания вне зависимости от национальной и конфессиональной принадлежности людей. Это является следствием верной линии в государственной политике, проводимой Общенациональным лидером Азербайджана Гейдаром Алиевым, ныне продолжаемым Президентом Азербайджана Ильхамом Алиевым и первым вице-президентом Азербайджана Мехрибан Алиевой.

\section{Список использованной литературы:}

Речь Президента Азербайджана Ильхама Алиева на церемонии открытия Православного религиозно-культурного центра 15 ноября 2013 года / bakuforum.az/ru/speech-b by-president-of-azerbaijan-mrilham-aliyev-2/?fid $=517$

Президент Азербайджанской Республики Ильхам Алиев об азербайджанской модели мультикультурализма. Баку, 2017.

Президент Азербайджанской Республики Ильхам Алиев: мультикультурализм является образом жизни в Азербайджане. 10 августа 2016 г. http://www.cbc.az/ru/news/ilxam-aliev-multikulturalizmiavliaetsia-obrazom-jizni-v-azerbaydjane

Алиев М.А. Религиозная толерантность в современном Азербайджане // Сборник научных трудов учёных. Москва: Наука, 2012, c. $296-299$.

Литературно-художественные истоки азербайджанского мультикультурализма. Баку, 2016.

Ломая стереотипы. Интервью телеканалу «Россия 1» вице-президента Азербайджана Мехрибан Алиевой // Каспій, № 37, 28 февраля, 2017 года, 16 с. 
Коран. Перевод и комментарии И.Ю. Крачковского. Б.: Язычы, $1990,744 \mathrm{c}$.

\section{РЕЗЮМЕ}

Статья посвящена одной из актуальных проблем современного периода в Азербайджанской Республике - мультикультурализму. Сегодня азербайджанская модель мультикультурализма является очень интересной и актуальной, так как данная модель изучается не только в стране, но и за рубежом. На сегодняшний день мультикультурализм является государственной политикой в стране.

Ключевые слова: Азербайджан, политика, мультикультурализм, толерантность, культура, религия 